\title{
PbSe Quantum Dot Solar Cells Based on Directly Synthesized Semi-conductive Inks
}

\author{
Yang Liu, ${ }^{1 \perp}$ Fei Li, ${ }^{1 \perp}$ Guozheng Shi, ${ }^{1}$ Zeke Liu,, $12 *$ Xiaofang Lin, ${ }^{3}$ Yao Shi, ${ }^{1}$ Yifan Chen, ${ }^{1}$ \\ Xing Meng, ${ }^{1}$ You Lv, ${ }^{1}$ Wei Deng, ${ }^{1}$ Xiangqiang Pan, ${ }^{3 *}$ and Wanli Ma ${ }^{l *}$
}

${ }^{1}$ Institute of Functional Nano \& Soft Materials (FUNSOM), Jiangsu Key Laboratory for Carbon-Based Functional Materials \& Devices, Joint International Research Laboratory of Carbon-Based Functional Materials and Devices, Soochow University, Suzhou, Jiangsu 215123, P.R. China.

${ }^{2}$ State Key Laboratory of Applied Optics, Changchun Institute of Optics, Fine Mechanics and Physics, Chinese Academy of Sciences, Changchun 130033, China.

${ }^{3}$ Jiangsu Key Laboratory of Advanced Functional Polymer Design and Application, College of Chemistry, Chemical Engineering and Materials Science, Soochow University, Suzhou 215123, China. 


\section{Chemical}

Lead iodide $\left(\mathrm{PbI}_{2}, 99+\%\right)$, selenourea $\left(\mathrm{CH}_{4} \mathrm{~N}_{2} \mathrm{Se}, \geq 99 \%\right), \mathrm{N}, \mathrm{N}$ dimethyl selenourea $\left(\mathrm{C}_{3} \mathrm{H}_{8} \mathrm{~N}_{2} \mathrm{Se}, \quad \geq 99 \%\right.$ ), 1,3-dicyclohexylcarbodiimide (99\%), Hydrogen selenide (Xundong Gas Co., Ltd), lead acetate trihydrate $\left(\mathrm{PbAc}_{2} \cdot 3 \mathrm{H}_{2} \mathrm{O}, 99 \%\right)$, hexamethyldisilathiane (TMSS, 98\%), ammonium acetate (AA, >98\%), cadmium oxide ( $\mathrm{CdO}, 99.99 \%)$, selenium powder (Se, 99.999\%), lead chloride $\left(\mathrm{PbCl}_{2}, 99 \%\right)$, Zinc acetate dihydrate $\left(\mathrm{ZnAc} 2 \cdot 2 \mathrm{H}_{2} \mathrm{O}\right.$, 99.0\%), potassium hydroxide $(\mathrm{KOH}, 99.98 \%)$, methanol $(\mathrm{MeOH}, 99.9 \%)$, chloroform (CF, 95\%), ethanol (Eth, 95\%), oleic acid (OA, 90\%), oleyamine (OLA, RG), 1-octadecene (ODE, 90\%), hexane (Hex, 95\%), isopropanol (IPA, 95\%), acetone (95\%), toluene (95\%), N,N'-dimethylformamide (DMF, 99.8\% anhydrous), butyl amine (BA, >99\%), 1,2ethanedithiol (EDT, 98\%), acetonitrile (ACN, 99\%).

\section{Synthesis of N, N-bicyclohexane selenourea (BCySA).}

$\mathrm{N}, \mathrm{N}$-bicyclohexane selenourea were synthesized according to the literature with some modifications. ${ }^{1}$ Hydrogen selenide was passed into a solution of 1,3dicyclohexylcarbodiimide $(10 \mathrm{~g}, 48.5 \mathrm{mmol})$ in diethyl ether $(110 \mathrm{~mL})$ for one hour under argon gas. The solution was stirred at room temperature for one hour. The mixture was filtered to remove the solvent, and the residue was washed with diethyl ether for three times, yielding 1,3-dicyclohexylselenourea as a grey solid. The yield was up to $98 \%$ and it was used directly without any further purification treatment. 


\section{One step synthesis and purification of PbSe QD inks.}

For the direct synthesis of $\mathrm{PbSe} \mathrm{QD}$ inks, $6 \mathrm{mmol} \mathrm{PbI}_{2}$ and $1 \mathrm{mmol}$ Se precursor was dissolved in $10 \mathrm{~mL}$ DMF in a nitrogen filled glovebox. The mixture was stirred at room temperature until the solids were totally dissolved. The reaction was initiated by rapid injection of $1 \mathrm{~mL}$ butylamine into the above precursor solution. The solution immediately turned black. After further reacting at room temperature for $5 \mathrm{~min}$, the crude solution was transferred into a nitrogen filled glovebox for purification. The QDs were isolated by precipitation with toluene as anti-solvent and centrifugation at $8000 \mathrm{rpm}$ for $5 \mathrm{~min}$. The obtained QD solids were stored in glovebox.

\section{Three-step synthesis and purification of PbSe QD inks.}

The procedures are the same as the reported work. ${ }^{2}$

Step 1. $0.512 \mathrm{~g}$ cadmium oxide $(\mathrm{CdO})$ was dispersed in a three-neck flask containing $4 \mathrm{~mL}$ oleic acid (OA), and $30 \mathrm{~mL}$ 1-octadecene (ODE). The mixture was stirred and degassed for $2 \mathrm{~h}$ at ambient temperature, and then temperature increased up to $100^{\circ} \mathrm{C}$ using a standard Schlenk line technique. Temperature of reaction mixture was further increased up to $225^{\circ} \mathrm{C}$. When mixture became transparent under $\mathrm{N}_{2}$ environment, $0.16 \mathrm{~g}$ Se dissolved in $5 \mathrm{~mL}$ ODE was quickly injected to it. The solution was naturally cooled down to $175^{\circ} \mathrm{C}$ within $5 \mathrm{~min}$, and then switched to water bath for rapid cooling. The obtained CdSe QDs were purified with several times chloroform/ethanol and precipitated via centrifugation. Finally, CdSe QDs were dried and dispersed in degassed ODE at $40 \mathrm{mg} \mathrm{mL}^{-1}$ concentration. 
Step 2. $1.7 \mathrm{~g}$ lead chloride $\left(\mathrm{PbCl}_{2}\right)$ and $20 \mathrm{~mL}$ oleylamine (OLA) were added in a three-neck flask and degassed at $60{ }^{\circ} \mathrm{C}$ for $2 \mathrm{~h}$. Subsequently, reaction temperature was increased to $115^{\circ} \mathrm{C}$. For cation exchange, purified $10 \mathrm{~mL}$ CdSe QDs solution was rapidly injected in above $\mathrm{Pb}$ precursor solution. Then, the reacting precursor turned to dark color indicating onset of nucleation phase. After $30 \mathrm{~s}$, flask was quickly immersed in a water bath. Later, $20 \mathrm{~mL}$ hexane and $16 \mathrm{~mL}$ OA were injected in at 75 and $40{ }^{\circ} \mathrm{C}$ temperatures, respectively. As-obtained product was tempestuously stirred at $40{ }^{\circ} \mathrm{C}$ for another $30 \mathrm{~min}$, and then naturally cooled at ambient temperature. For PbSe QDs purification, hexane/ethanol solution was added in QDs solution for repeated washing and centrifugation. Finally, as-obtained $\mathrm{PbSe}$ QDs were dispersed in hexane at $20 \mathrm{mg} \mathrm{mL}^{-1}$ for further use.

Step 3. $5 \mathrm{~mL}$ oleate-capped $\mathrm{PbSe}$ QDs (20 mg mL-1 in hexane) and $0.35 \mathrm{mmol} \mathrm{PbI}_{2}$ in $6 \mathrm{~mL}$ DMF were intermingled together at ambient temperature. Upon vigorous shaking, the OA ligand on the surface of PbSe QDs were moved and then transferred from nonpolar phase to the polar DMF phase. After ligand exchange, the hexane layer became transparent then was decanted. The PbSe QDs/DMF solution was thoroughly washed three times with hexane to completely remove the oleate ligands. Subsequently, PbSe QDs were centrifuged at $6000 \mathrm{rpm}$ for $5 \mathrm{~min}$ and then desiccated for $20 \mathrm{~min}$ to get dry product. For film deposition, the PbSe QDs were suspended in DMF and BA (7:3 v/v) with concentration of $550 \mathrm{mg}$ $\mathrm{mL}^{-1}$.

\section{Synthesis of oleate capped PbS QDs.}


The synthesis is the same as our previous report. ${ }^{3} 10 \mathrm{mmol}$ of lead acetate trihydrate and 7 $\mathrm{g}$ of OA were dissolved in $60 \mathrm{~g}$ of ODE in a three-neck flask by heating the mixture to 100 ${ }^{\circ} \mathrm{C}$ under vacuum for $2 \mathrm{~h}$. The sulfide precursor was prepared separately by mixing $1 \mathrm{~mL}$ of hexamethyldisilathiane and $9 \mathrm{~mL}$ of 1-octadecene. The reaction was initiated by rapid injection of the sulfide precursor into the lead precursor solution. After synthesis, the solution was transferred into a nitrogen-filled glovebox. QDs were purified by adding isopropanol, followed by centrifugation. The extracted QDs were re-dispersed in hexane and acetone was added to precipitate QDs, followed by centrifugation. Then the QDs were stored in the glovebox. For device fabrication, PbS QDs were re-dispersed in hexane (40

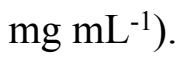

\section{Synthesis of $\mathrm{ZnO}$ nanoparticles.}

$\mathrm{ZnO}$ nanoparticles were synthesized according to the literature with some modifications. ${ }^{4}$ Zinc acetate dihydrate $(2.95 \mathrm{~g})$ was dissolved in $125 \mathrm{~mL}$ of methanol at $60{ }^{\circ} \mathrm{C}$. Potassium hydroxide ( $1.48 \mathrm{~g})$ was dissolved in $65 \mathrm{~mL}$ of methanol. The potassium hydroxide solution was slowly added to the zinc acetate solution and the solution was left stirring at $63{ }^{\circ} \mathrm{C}$ for

$3 \mathrm{~h}$. $\mathrm{ZnO}$ nanocrystals were precipitated by centrifugation and then washed twice with methanol followed by centrifugation. Finally, $10 \mathrm{~mL}$ of chloroform and $10 \mathrm{~mL}$ of methanol were added to the precipitates and the solution was filtered with a $0.45 \mu \mathrm{m}$ filter.

\section{Field effect transistor (FET) fabrication.}


Before the device fabrication, the silicon substrate with a $300 \mathrm{~nm}$ thick thermally grown $\mathrm{SiO}_{2}$ layer was cleaned by acetone and isopropanol. After a 15 min UV treatment, the substrate was immersed in $0.1 \mathrm{v} \%$ phenyltrichlorosilane (PTS)/toluene solution for $20 \mathrm{~min}$ at room temperature to form a self-assembled monolayer of PTS. Then, PbSe-I film with a thickness of $100 \mathrm{~nm}$ was spin coated on the PTS-functionalized substrate. After that, $2 \mathrm{~nm}$ thick LiF and $200 \mathrm{~nm}$ thick $\mathrm{Al}$ were subsequently deposited through a metal mask to form source/drain electrodes. The channel length and width were $10 \mu \mathrm{m}$ and $10 \mathrm{~mm}$, respectively. To ensure good electrical characteristics, the devices were tested in a $\mathrm{N}_{2}$-filled glove box.

\section{Solar cell fabrication.}

ITO-coated glass substrates were sonicated in sequence with acetone, deionized water, acetone, IPA and acetone for $15 \mathrm{~min}$, respectively. The substrates were then treated with oxygen plasma for $15 \mathrm{~min}$. The $\mathrm{ZnO}$ layer $(80 \mathrm{~nm})$ was fabricated by spin-coating the $\mathrm{ZnO}$ nanoparticle solution onto the ITO substrates at $2500 \mathrm{rpm}$ for $20 \mathrm{~s}$. The $\mathrm{ZnO}$ film was used without thermal annealing. The PbSe QD layer was fabricated by spin-coating $\sim 30 \mu \mathrm{l}$ of a $300 \mathrm{mg} \cdot \mathrm{mL}^{-1}$ solution of QDs in DMF at $2000 \mathrm{rpm}$ for $45 \mathrm{~s}$, followed by $10 \mathrm{~min}$ annealing at $70{ }^{\circ} \mathrm{C}$ in a nitrogen-filled glovebox. For the EDT treated PbS QDs layers, $20 \mathrm{mg} / \mathrm{mL}$ oleate capped PbS QDs in hexane were spin-coated at $2500 \mathrm{rpm}$ for $20 \mathrm{~s}$, followed with EDT/IPA (v/v: 0.04\%) solution treatment for $30 \mathrm{~s}$ and acetonitrile rinsing for twice. Two layers of PbS-EDT were deposited. After $12 \mathrm{~h}$ of exposure to dry air, a $80 \mathrm{~nm}$ thick gold electrode was thermally evaporated through a shadow mask to fix a total active area of 
$0.0725 \mathrm{~cm}^{2}$. The devices are stored in ambient air (humidity around 30\%) for the air stability test.

\section{Measurement and characterization.}

UV-vis NIR spectra were recorded on a Perkin Elmer model Lambda 750. The second harmonic (400 nm) of a Ti:sapphire laser (Coherent, Mira 900, repetition rate $76 \mathrm{MHz}$ ) was used to excite the samples. The optical emission was recorded by a cooled array detector (Andor, iDus $1.7 \mu \mathrm{m}$ ). Time-resolved PL spectra were detected using a Hamamatsu streak camera with a cathode sensitive to near-IR radiation. The PbSe QD films for UPS/XPS test were made by spin-coating $200 \mathrm{~nm}$ thick film onto silicon substrate. Current-voltage characteristics were recorded using a Keithley 2400 (I-V) digital source meter under a simulated AM $1.5 \mathrm{G}$ solar irradiation at $100 \mathrm{~mW} \cdot \mathrm{cm}^{-2}(\mathrm{Newport}$, Class AAA solar simulator, 94023A-U). The light intensity is calibrated by a certified Oriel Reference Cell $(91150 \mathrm{~V})$ and verified with a NREL calibrated Hamamatsu S1787-04 diode. Voltage swept from -1 to $0.1 \mathrm{~V}$ (revrese sweep) and 0.1 to $-1 \mathrm{~V}$ (forward sweep) with the speed of $0.01 \mathrm{~V}$ per point and a dwell time of $10 \mathrm{~ms}$.

\section{Synthesis cost estimation.}

Estimated cost for conventional three-step synthesis process:

For the hot injection synthesis of oleic acid capped CdSe QDs, $20 \mathrm{mmol} \mathrm{CdO}, 20 \mathrm{~mL}$ OA, 
$190 \mathrm{~mL}$ ODE, $0.8 \mathrm{~g}$ Se powder are needed to obtain around $3 \mathrm{~g}$ CdSe-OA QDs. For the purification of CdSe-OA QDs, $150 \mathrm{~mL}$ chloroform, $150 \mathrm{~mL}$ ethanol and $10 \mathrm{~mL}$ ODE are needed. During cation exchange and purification process, $30 \mathrm{mmol} \mathrm{PbCl}_{2}, 100 \mathrm{~mL}$ oleylamine (OLA), $200 \mathrm{~mL}$ hexane, $300 \mathrm{~mL}$ ethanol, 80mL OA, and $3 \mathrm{~g}$ CdSe QDs are needed to obtain about 2.5 g PbSe-OA QDs. And during solution phase ligand exchange and purification process, $8.75 \mathrm{mmol} \mathrm{PbI}_{2}, 150 \mathrm{~mL} \mathrm{DMF}$, 2L hexane and 2.5g PbSe-OA QDs are needed. Therefore, for conventional three step method, the synthesis cost in our lab of $1 \mathrm{~g} \mathrm{PbSe}$ QD solid is $¥ 665.5$ or $\$ 95.0$ based on the material cost in Table S2. In addition, the high temperature heating and lab cost are not taken into account yet.

Estimated cost for the direct synthesis of PbSe QD inks with $S A$ as Se precursor: $15 \mathrm{mmol} \mathrm{PbI}_{2}, 2.5 \mathrm{mmol} \mathrm{SA}, 25 \mathrm{~mL}$ DMF and $2.5 \mathrm{~mL} \mathrm{BA}$ were used as precursors and solvents. Toluene was used as anti-solvent. As shown in Table S3, the total cost for the direct synthesis of $1 \mathrm{~g} \mathrm{PbSe}$ QD solid with SA in our lab is $¥ 276.5$ or $\$ 39.5$.

Estimated cost for the direct synthesis of PbSe QD inks with BCySA as Se precursor: $15 \mathrm{mmol} \mathrm{PbI}_{2}, 0.515 \mathrm{~g}$ 1,3-dicyclohexylcarbodiimide, $0.202 \mathrm{~g}$ hydrogen selenide, $25 \mathrm{~mL}$ DMF and $2.5 \mathrm{~mL}$ BA were used as precursors and solvents. Toluene was used as antisolvent. As shown in Table S4, the total cost to directly synthesis $1 \mathrm{~g}$ PbSe QD solid with BCySA in our lab is only $¥ 83.9$ or $\$ 12.0$.

Based on the same cost estimation method, this price is much lower than the cost of 95.0 
$\$ \cdot \mathrm{g}^{-1}$ for conventional PbSe QDs obtained in our lab. Furthermore, the total synthesis and purification time is less than 1 hour. The synthesis cost of PbSe QD ink is expected to be further reduced in practical application, due to the price reduction of raw materials with increasing scale.

Table S1. The summary of the solar cells with PCE $>6 \%$ based on the PbSe QD inks prepared by the conventional three-step synthesis method and our direct synthesis method.

\begin{tabular}{|c|c|c|c|c|c|c|}
\hline \multirow{2}{*}{ Solar cell structures } & $V_{\text {oc }}$ & $J_{\mathrm{sc}}$ & $\mathbf{F F}$ & PCE & \multicolumn{2}{|c|}{ Published } \\
\hline & (V) & $\left(\mathrm{mA} / \mathrm{cm}^{2}\right)$ & $(-)$ & (\%) & year & Ref \\
\hline $\mathrm{ITO} / \mathrm{ZnO} / \mathrm{PbSe}-\mathrm{PbI}_{2} / \mathrm{PbS}-\mathrm{EDT} / \mathrm{Au}$ & 0.57 & 28.1 & 0.66 & 10.68 & 2019 & 2 \\
\hline $\mathrm{ITO} / \mathrm{SnO}_{2} / \mathrm{PCBM} / \mathrm{PbSe}-\mathrm{PbI}_{2} / \mathrm{PbS}-\mathrm{EDT} / \mathrm{Au}$ & 0.54 & 28.4 & 0.68 & 10.4 & 2019 & 5 \\
\hline $\begin{array}{l}\mathrm{ITO} / \mathrm{ZnO} / \mathrm{PbSe} \text { ink (direct synthesis)/PbS } \\
\mathrm{EDT} / \mathrm{Au}\end{array}$ & 0.61 & 25.39 & 0.67 & 10.38 & \multicolumn{2}{|c|}{ This work } \\
\hline $\mathrm{FTO} / \mathrm{SnO}_{2} / \mathrm{PbSe}-\mathrm{PbI}_{2} / \mathrm{PbS}-\mathrm{EDT} / \mathrm{Au}$ & 0.57 & 24.8 & 0.67 & 9.6 & 2020 & 6 \\
\hline $\begin{array}{l}\mathrm{ITO} / \mathrm{ZnO} / \mathrm{PbSe}\left(\mathrm{CsPbBr}_{x} \mathrm{I}_{1-\mathrm{-}}\right)-\mathrm{PbI}_{2} / \mathrm{PbS}- \\
\mathrm{EDT} / \mathrm{Au}\end{array}$ & 0.56 & 25.7 & 0.64 & 9.2 & 2018 & 7 \\
\hline $\begin{array}{l}\mathrm{FTO} / \mathrm{TiO} / \mathrm{Sb}: \mathrm{SnO}_{2} / \mathrm{PbSe}^{-} \mathrm{PbI}_{2}, \mathrm{MPA}, \mathrm{CsPbBr} \\
\text { QDs/Au }\end{array}$ & 0.50 & 26.7 & 0.58 & 7.9 & 2018 & 8 \\
\hline ITO/TiO $/ 2 / \mathrm{PbSe}\left(\mathrm{CdCl}_{2}\right)-\mathrm{PbI}_{2} / \mathrm{CsPbBr}_{3} \mathrm{QDs} / \mathrm{Au}$ & 0.48 & 23.9 & 0.62 & 7.2 & 2017 & 9 \\
\hline $\mathrm{FTO} / \mathrm{TiO}_{2} / \mathrm{PbSe}\left(\mathrm{ZnCl}_{2}\right)-\mathrm{PbI}_{2} / \mathrm{PbSe}-\mathrm{MPA} / \mathrm{Au}$ & 0.52 & 24.0 & 0.50 & 6.50 & 2015 & 10 \\
\hline
\end{tabular}


Table S2. The chemicals used for the synthesis of $1 \mathrm{~g}$ PbSe QD inks through conventional three-step synthesis process.

\begin{tabular}{|c|c|c|c|c|c|}
\hline Chemical & Supplier & Purity & Price & Amount & Cost \\
\hline $\mathrm{CdO}$ & Aladdin & $99.99 \%$ & $¥ 2.61 / \mathrm{g}$ & $2.56 \mathrm{~g}$ & $¥ 6.7$ \\
\hline $\mathrm{OA}$ & Alfa & $90 \%$ & $¥ 0.35 / \mathrm{mL}$ & $100 \mathrm{~mL}$ & $¥ 35.0$ \\
\hline $\mathrm{ODE}$ & JK & $90 \%$ & $¥ 0.26 / \mathrm{mL}$ & $200 \mathrm{~mL}$ & $¥ 52.0$ \\
\hline $\mathrm{OLA}$ & Acros & RG & $¥ 2.22 / \mathrm{mL}$ & $100 \mathrm{~mL}$ & $¥ 222.0$ \\
\hline $\mathrm{Se}$ & Alfa & 99.999 & $¥ 14.26 / \mathrm{g}$ & $0.8 \mathrm{~g}$ & $¥ 11.4$ \\
\hline $\mathrm{PbCl}_{2}$ & Alfa & $99 \%$ & $¥ 7.84 / \mathrm{g}$ & $8.34 \mathrm{~g}$ & $¥ 65.4$ \\
\hline Hexane & $\begin{array}{c}\text { Sinopharm } \\
\text { Group }\end{array}$ & $97.5 \%$ & $¥ 0.038 / \mathrm{mL}$ & $2 \mathrm{~L}$ & $¥ 76.0$ \\
\hline Chloroform & $\begin{array}{c}\text { Sinopharm } \\
\text { Group }\end{array}$ & $95 \%$ & $¥ 0.021 / \mathrm{mL}$ & $150 \mathrm{~mL}$ & $¥ 3.1$ \\
\hline Ethanol & $\begin{array}{c}\text { Sinopharm } \\
\text { Group }\end{array}$ & $95 \%$ & $¥ 0.018 / \mathrm{mL}$ & $450 \mathrm{~mL}$ & $¥ 8.1$ \\
\hline DMF & $\begin{array}{c}\text { Sigma- } \\
\text { Aldrich }\end{array}$ & $99.8 \%$ & $¥ 1.128 / \mathrm{mL}$ & $150 \mathrm{~mL}$ & $¥ 169.2$ \\
\hline $\mathrm{PbI}_{2}$ & Adamas & $99+\%$ & $¥ 4.125 / \mathrm{g}$ & $4.03 \mathrm{~g}$ & $¥ 16.6$ \\
\hline Total & \multicolumn{7}{|l}{} & & $¥ 665.5(\$ 95.0)$ \\
\hline
\end{tabular}

Table S3. The chemicals needed for the synthesis of $1 \mathrm{~g}$ PbSe QDs through one step synthesis process with SA as Se precursor.

\begin{tabular}{|c|c|c|c|c|c|}
\hline Chemical & Supplier & Purity & Price & Amount & Cost \\
\hline Selenourea & Sigma-Aldrich & $99 \%$ & $¥ 700 / \mathrm{g}$ & $0.307 \mathrm{~g}$ & $¥ 214.9$ \\
\hline $\mathrm{DMF}$ & Sigma-Aldrich & $99.8 \%$ & $¥ 1.128 / \mathrm{mL}$ & $25 \mathrm{~mL}$ & $¥ 28.2$ \\
\hline $\mathrm{PbI}_{2}$ & Adamas & $99+\%$ & $¥ 4.125 / \mathrm{g}$ & $6.915 \mathrm{~g}$ & $¥ 28.5$ \\
\hline $\mathrm{BA}$ & TCL & $>99 \%$ & $¥ 0.369 / \mathrm{mL}$ & $2.5 \mathrm{~mL}$ & $¥ 0.9$ \\
\hline Toluene & $\begin{array}{c}\text { Sinopharm } \\
\text { Group }\end{array}$ & $95 \%$ & $¥ 0.04 / \mathrm{mL}$ & $100 \mathrm{~mL}$ & $¥ 4.0$ \\
\hline Total & & & & & $\begin{array}{l}¥ 276.5 \\
\end{array}$ \\
& & & & & $(\$ 39.5)$ \\
\hline
\end{tabular}


Table S4. The chemicals needed for the synthesis of $1 \mathrm{~g}$ PbSe QDs through one step synthesis process with BCySA as Se precursor.

\begin{tabular}{|c|c|c|c|c|c|}
\hline Chemical & Supplier & Purity & Price & $\begin{array}{c}\text { Amoun } \\
\mathrm{t}\end{array}$ & Cost \\
\hline $\begin{array}{c}1,3- \\
\text { dicyclohexylcar } \\
\text { bodiimide }\end{array}$ & Alfa & $99 \%$ & $¥ 4.16 / \mathrm{g}$ & $0.515 \mathrm{~g}$ & $¥ 2.1$ \\
\hline $\begin{array}{c}\text { Hydrogen } \\
\text { selenide }\end{array}$ & $\begin{array}{c}\text { Xundong Gas } \\
\text { Co., Ltd }\end{array}$ & & $¥ 100 / \mathrm{g}$ & $0.202 \mathrm{~g}$ & $¥ 20.2$ \\
\hline DMF & $\begin{array}{c}\text { Sigma- } \\
\text { Aldrich }\end{array}$ & $99.8 \%$ & $¥ 1.128 / \mathrm{mL}$ & $25 \mathrm{~mL}$ & $¥ 28.2$ \\
\hline $\mathrm{PbI}_{2}$ & Adamas & $99+\%$ & $¥ 4.125 / \mathrm{g}$ & $6.915 \mathrm{~g}$ & $¥ 28.5$ \\
\hline BA & TCL & $>99 \%$ & $¥ 0.369 / \mathrm{mL}$ & $2.5 \mathrm{~mL}$ & $¥ 0.9$ \\
\hline Toluene & $\begin{array}{c}\text { Sinopharm } \\
\text { Group }\end{array}$ & $95 \%$ & $¥ 0.04 / \mathrm{mL}$ & $100 \mathrm{~mL}$ & $¥ 4.0$ \\
\hline Total & & & & & $\begin{array}{c}¥ 83.9 \\
(\$ 12.0)\end{array}$ \\
\hline
\end{tabular}

Table S5. Time-resolve PL curve of PbSe-I solution.

\begin{tabular}{l|l|l|l|l|l}
\hline & $\mathrm{B}_{1}$ & $\tau_{1}(\mu \mathrm{s})$ & $\mathrm{B}_{2}$ & $\tau_{2}(\mu \mathrm{s})$ & $\tau_{\text {avg }}(\mu \mathrm{s})$ \\
\hline PbSe-I & 112 & 0.477 & 59.9 & 2.46 & 1.16 \\
\hline
\end{tabular}

The transient PL decay curves of PbSe-I solution fitted with a bi-exponential decay function of $\mathrm{I}(\mathrm{t})=\mathrm{B}_{1} \times \exp \left[-\mathrm{t} / \tau_{1}\right]+\mathrm{B}_{2} \times \exp \left[-\mathrm{t} / \tau_{2}\right]$. Here, $\mathrm{B}_{1}$ and $\mathrm{B}_{2}$ correspond to the decay amplitudes of the curve. $\tau_{1}$ and $\tau_{2}$ correspond to the decay time constants of fast and slow components, respectively. The average lifetime $\tau_{\text {avg }}$ was calculated by $\tau_{\text {avg }}=$ $\left(\mathrm{B}_{1} \tau_{1}+\mathrm{B}_{2} \tau_{2}\right) /\left(\mathrm{B}_{1}+\mathrm{B}_{2}\right)$. And the calculated $\tau_{\text {avg }}$ was $1.16 \mu$ s. 
(a)

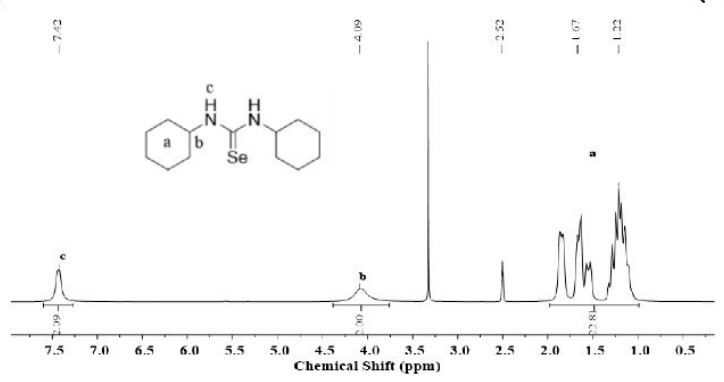

(b)

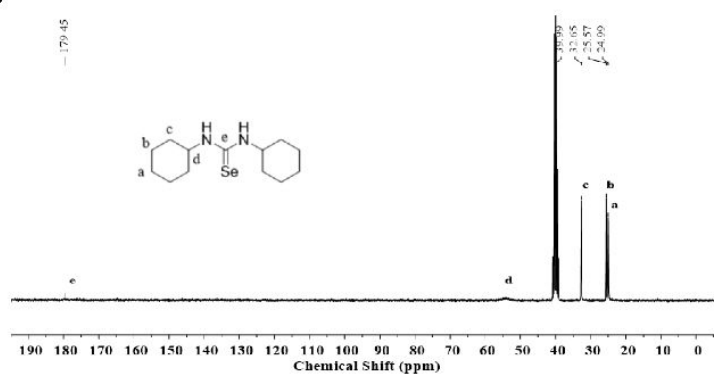

Figure S1. (a) ${ }^{1} \mathrm{H}$ nuclear magnetic resonance $\left({ }^{1} \mathrm{H}-\mathrm{NMR}\right)$ and $(\mathrm{b}){ }^{13} \mathrm{C}-\mathrm{NMR}$ of the $\mathrm{N}, \mathrm{N}-$ bicyclohexane selenourea (BCySA).

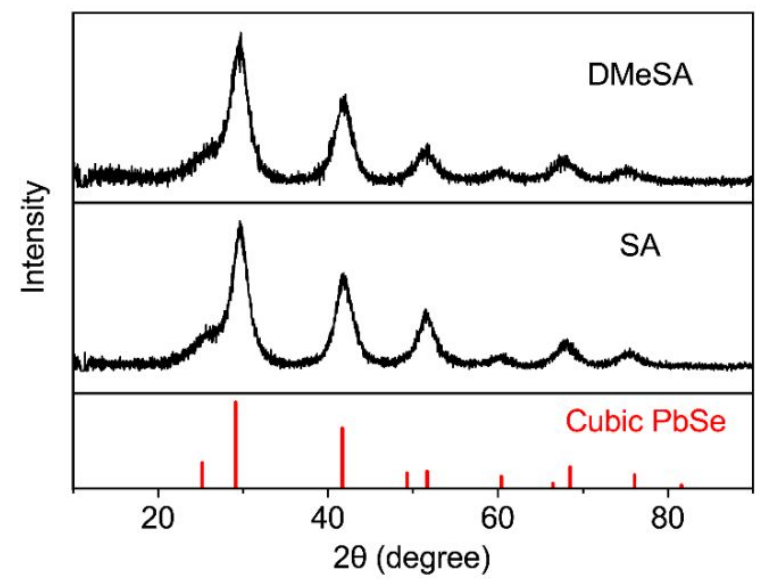

Figure S2. X-Ray Diffraction (XRD) spectrum of PbSe QDs synthesized by the two Se precursors. 


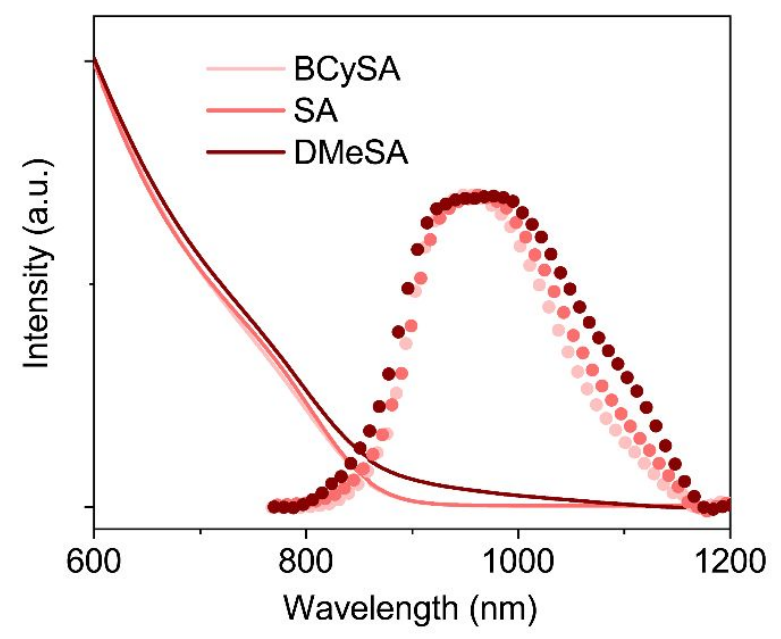

Figure S3. Absorption and photoluminescence spectra of PbSe QDs synthesized using different $\mathrm{Se}$ precursors at room temperature. $\mathrm{Pb} / \mathrm{Se}$ precursor ratio is 6:1.

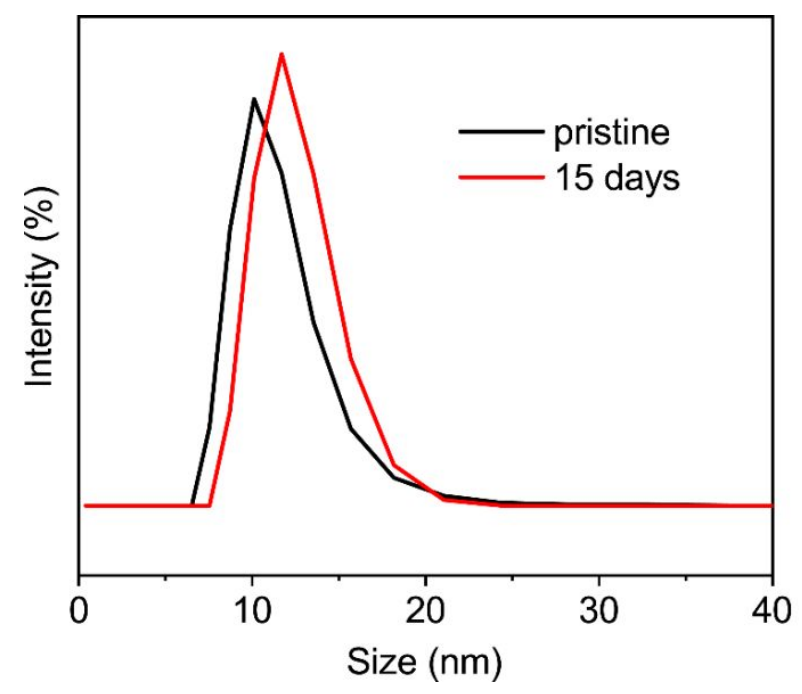

Figure S4. Dynamic Light Scattering (DLS) spectra of pristine and aged PbSe QDs. 


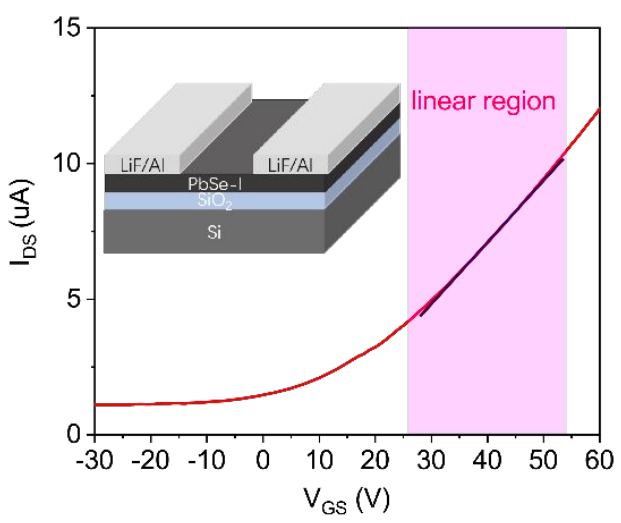

Figure S5. Field-effect transistor (FET) of PbSe QDs. The inset figure demonstrated the scheme of the FET structure. The carrier mobility is calculated by linear region.

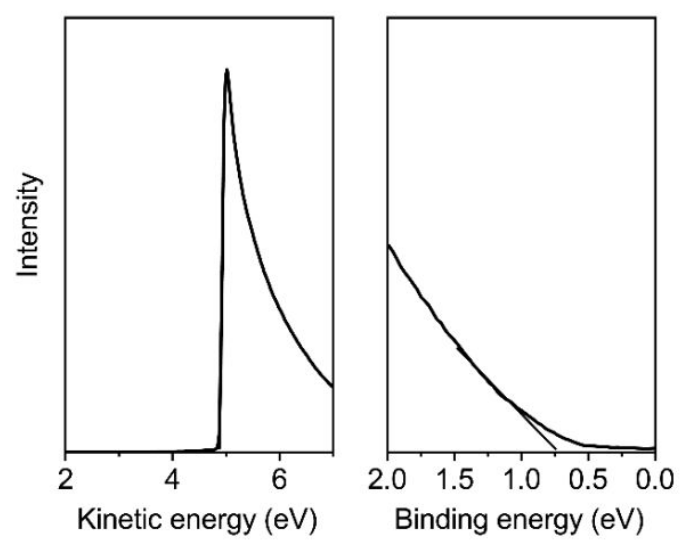

Figure S6. Ultraviolet photoelectron spectrum (UPS) of PbSe QDs film. The Fermi level can be calculated at $4.81 \mathrm{eV}$, the valence band maximum can be calculated at $5.53 \mathrm{eV}$. 


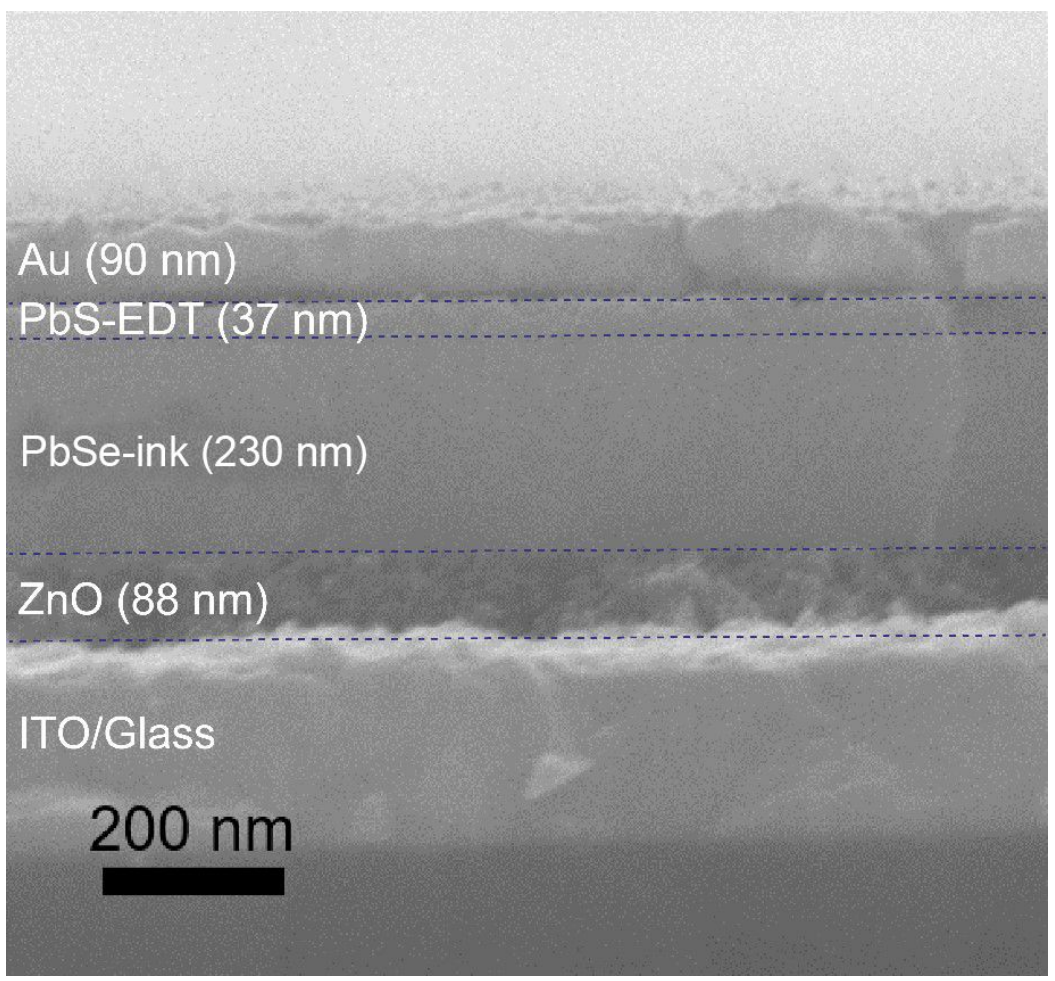

Figure S7. Cross-sectional SEM image of the photovoltaic device.
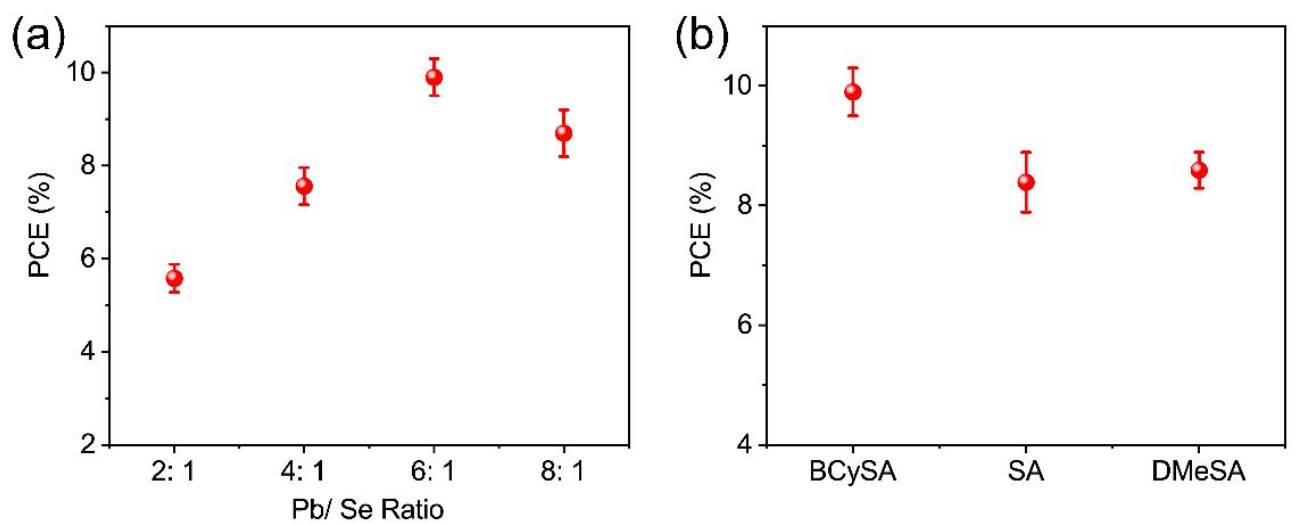

Figure S8. Device performance based on $\mathrm{PbSe}$ QDs synthesized with (a) different $\mathrm{Pb} / \mathrm{Se}$ ratios and (b) different Se precursors. The error bar in figures represent the standard deviation between different devices. The Se precursor in (a) is BCySA. The $\mathrm{Pb} / \mathrm{Se}$ ratio in (b) is $6: 1$. 


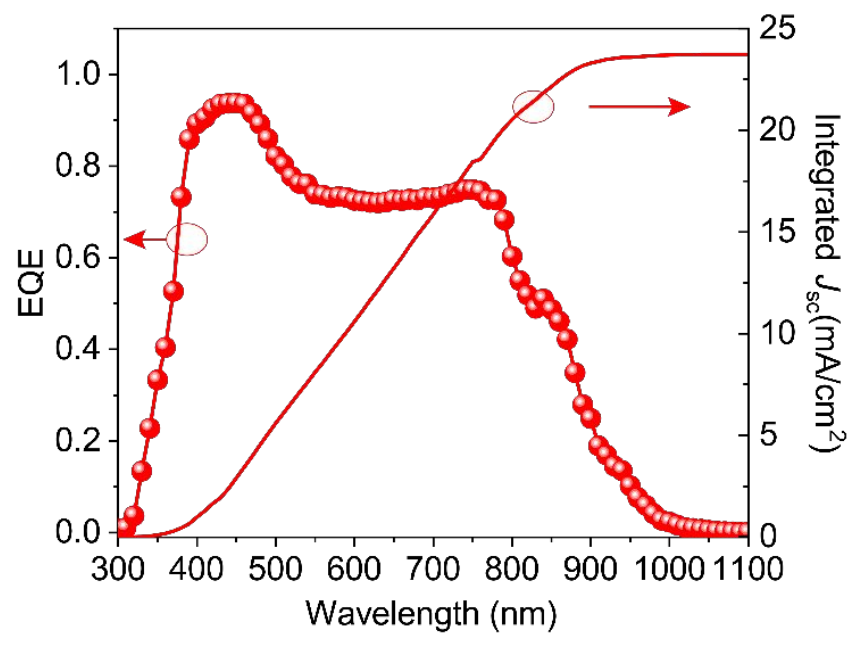

Figure S9. External quantum efficiency (EQE) spectrum of the optimized PbSe QD device, with an integrated $J_{s c}$ of $24.01 \mathrm{~mA} \cdot \mathrm{cm}^{-2}$.

\section{Supplementary References}

1. Blum, T.; Ermert, J.; Coenen, H. H. Synthesis of Asymmetric $\left[{ }^{75} \mathrm{Se}\right]$ Selenoethers via Carbodiimides. J. Labelled Compd. Rad., 2001, 44, 587.

2. Ahmad, W.; He, J.; Liu, Z.; Xu, K.; Chen, Z.; Yang, X.; Li, D.; Xia, Y.; Zhang, J.; Chen, C. Lead Selenide (PbSe) Colloidal Quantum Dot Solar Cells with $>10 \%$ Efficiency. Adv. Mater., 2019, 31, 1900593.

3. Wang, Y.; Lu, K.; Han, L.; Liu, Z.; Shi, G.; Fang, H.; Chen, S.; Wu, T.; Yang, F.; Gu, M.; Zhou, S.; Ling, X.; Tang, X.; Zheng, J.; Loi, M. A.; Ma, W. In Situ Passivation for Efficient PbS Quantum Dot Solar Cells by Precursor Engineering. Adv. Mater., 2018, 30, 1704871.

4. Yang, F.; Xu, Y.; Gu, M.; Zhou, S.; Wang, Y.; Lu, K.; Liu, Z.; Ling, X.; Zhu, Z.; Chen, J.; Wu, Z.; Zhang, Y.; Xue, Y.; Li, F.; Yuan, J.; Ma, W. Synthesis of Cesium-Doped ZnO Nanoparticles as an Electron Extraction Layer for Efficient PbS Colloidal Quantum Dot Solar Cells. J. Mater. Chem. A, 2018, 6, 17688.

5. Hu, L.; Geng, X.; Singh, S.; Shi, J.; Hu, Y.; Li, S.; Guan, X.; He, T.; Li, X.; Cheng, Z.; Patterson, R.; Huang, S.; Wu, T. Synergistic Effect of Electron Transport Layer and Colloidal Quantum Dot Solid Enable PbSe Quantum Dot Solar Cell Achieving over 10 \% Efficiency. Nano Energy 2019, 64, 103922. 6. Zhu, M.; Liu, X.; Liu, S.; Chen, C.; He, J.; Liu, W.; Yang, J.; Gao, L.; Niu, G.; Tang, J.; Zhang, J. Efficient PbSe Colloidal Quantum Dot Solar Cells Using $\mathrm{SnO}_{2}$ as a Buffer Layer. ACS Appl. Mater. Inter. 2020, 12, 2566.

7. Hu, L.; Zhang, Z.; Patterson, R. J.; Shivarudraiah, S. B.; Zhou, Z.; Ng, M.; Huang, S.; Halpert, J. E. PbSe Quantum Dot Passivated Via Mixed Halide Perovskite Nanocrystals for Solar Cells with over 
9\% Efficiency. Solar RRL 2018, 2, 1800234.

8. $\quad$ Chen, Z.; Zhang, Z.; Yang, J.; Chen, W.; Teh, Z. L.; Wang, D.; Yuan, L.; Zhang, J.; Stride, J. A.; Conibeer, G. J.; Patterson, R. J.; Huang, S. Improving Carrier Extraction in a PbSe Quantum Dot Solar Cell by Introducing a Solution-Processed Antimony-Doped $\mathrm{SnO}_{2}$ Buffer Layer. J. Mater. Chem. C 2018, 6,9861.

9. Zhang, Z.; Chen, Z.; Zhang, J.; Chen, W.; Yang, J.; Wen, X.; Wang, B.; Kobamoto, N.; Yuan, L.; Stride, J. A.; Conibeer, G. J.; Patterson, R. J.; Huang, S. Significant Improvement in the Performance of PbSe Quantum Dot Solar Cell by Introducing a $\mathrm{CsPbr}_{3}$ Perovskite Colloidal Nanocrystal Back Layer. Adv. Energy Mater. 2017, 7, 1601773.

10. Kim, S.; Marshal, A. R.; Kroupa, D. M.; Miller, E. M.; Luther, J. M.; Jeong, S.; Beard, M. C. Air-Stable and Efficient PbSe Quantum-Dot Solar Cells Based Upon ZnSe to PbSe Cation-Exchanged Quantum Dots. ACS Nano 2015, 9, 8157. 